\title{
Exploring the Relationships Between Learning Space and Student Learning in Higher Education: A Comparative Case Study in China
}

Ji Yu

\begin{abstract}
The landscape of learning space design in higher education is undergoing a transformation. During the past decade, flexible, innovative learning spaces have been established around the world in response to the changing perspectives on how knowledge is discovered and what constitutes important and appropriate higher education in contemporary society.
\end{abstract}

\section{Introduction}

The landscape of learning space design in higher education is undergoing a transformation. During the past decade, flexible, innovative learning spaces have been established around the world in response to the changing perspectives on how knowledge is discovered and what constitutes important and appropriate higher education in contemporary society (e.g. Beetham \& Sharpe, 2013; Harrison \& Hutton, 2014; JISC, 2006; Oblinger, 2006). Characteristics of these spaces include motivating learners and promoting learning as an activity, supporting interdisciplinary and collaborative learning, providing a personalised and inclusive environment and being flexible in the face of changing needs. Technology usually plays a vital part in achieving these aims.

In contrast with the school sector, the existence of evidence on the link between spatial design and pedagogical effectiveness in higher education is still sparse. Some exceptions include the works of Brooks $(2011,2012)$ and Walker et al. (2011), who have partnered with instructors and conducted a series of quasi-experimental studies to investigate the impact of learning space upon students' learning behaviour and learning outcomes. It has been argued that there is a great need for rigorous and multilayered models and knowledge of the role of learning space in influencing and

J. Yu (凶)

Graduate School of Education, Peking University Beijing, No. 5 Yi Heyuan Road,

Haidian District, Beijing 100871, China

e-mail: summersonyj@163.com

W. Imms and T. Kvan (eds.), Teacher Transition into Innovative Learning Environments, https://doi.org/10.1007/978-981-15-7497-9_18 
supporting student learning in higher education (Ellis \& Goodyear, 2016; Mirijamdotter et al., 2006; Strange \& Banning, 2001; Temple, 2008). The present study is an attempt to remedy the situation.

\section{Student Learning Research in Higher Education and Discussions on "Chinese Leaners"}

This study draws on theories and concepts in student learning research (Biggs, 1993; Richardson, 2000), mainly situated in the cognitive psychology of education, in order to provide an insightful and solid way to understand the complex student learning process and discuss relatively 'desirable' or 'less desirable' learning in contemporary society. Student learning has been an ongoing subject of study, and it includes the following outline frameworks and broad concepts (Entwistle et al., 2002): (1) Curriculum frameworks and their influences on learning; (2) students' approaches to learning; (3) the teaching-learning context (environment) and students' perceptions of it; and (4) learning outcomes.

The theoretical underpinnings of this study are particularly rooted in the literature concerning Students' Approaches to Learning (SAL). The research tradition that originated in the 1970s has exerted a seminal impact in studying how to assess and improve the quality of student learning in higher education. An approach to learning is conceptualised in terms of cognitive strategies and motivation. Two distinct approaches have been identified repeatedly (Biggs 1988; Entwistle \& Ramsden 1983; Marton \& Säljö, 1984; Schmeck, 1988). Surface approaches to learning refer to students employing surface learning processes (e.g. rote memorisation of course materials) for the purpose of assessment, while deep approaches to learning mean that students use deep learning processes (e.g. seeking for meaning, understanding and relating ideas) with an intrinsic interest in learning and understanding.

Over the last few decades, the research domain has further flourished. Researchers (Short \& Weisberg-Benchell, 1989; Vermunt \& Verloop, 1999) have compared different taxonomies in studies and categorised them into three main dimensions: cognitive processing activities, affective or motivational learning activities and regulative activities. Cognitive processing activities refer to how students engage in processing subject matter, which leads directly to learning outcomes. Affective learning activities are related to the emotions that arise during learning, and the activities that students employ that lead to a mood may have a positive, neutral or negative effect on the learning processes. Regulative activities refer to students exerting control over their cognitive and affective activities during learning. This categorisation serves as a point of departure in conceptualising student learning in the present study.

In contrast with the extensive literature in the west, this area of research in China is in its infancy-only a small number of studies have been published. There have been some discussions on "Chinese learners" - an old stereotype of Chinese students 
is that they are passive rote learners, concerned mainly with memorising the information (Ballard \& Clanchy, 1984; Murphy, 1987; Samuelowicz, 1987). But recent questionnaire and interview-based research refute this idea as Chinese students from East Asian countries outperform their Western counterparts in international comparisons (Hau \& Ho, 2010); and it is suggested that, unlike Western students who normally adopt either a deep or surface approach to learning, ethnically Chinese students tend to adopt a distinctive approach to studying that combines memorising with understanding (Kember, 1996; Watkin \& Biggs, 1996).

However, it should be noted that the majority of existing evidence has not been based on students from mainland China but on ethically Chinese students in Hong Kong, where a Western higher educational system is operated. Only very few studies have studied the mainland Chinese students (Lu, 2003; Richardson \& Sun, 2016; Zhu et al., 2008a, b), and current evidence is far from sufficient to gain a holistic and accurate picture of "Chinese learners" and to conclude how Chinese students go about their learning are culturally determined. Furthermore, as China is composed of 56 ethnic groups and the uneven education development between different regions is still manifested, treating "Chinese learners" as a homogeneous group may be simplistic and inappropriate.

\section{The Present Study}

This study aims to explore the relationship between learning space and student learning in higher education through empirical work. It employs a comparative case study design. The case study allows for a rich, vivid description and an in-depth analysis of certain phenomena, and is powerful in revealing multi-fold dimensions of exploratory research. Moreover, multiple-case study helps to deepen understanding and enhance generalisability (Geertz, 1973; Yin, 2009). The study highlights the crucial student view as the current spatial design in higher education lacks a student's perspective. Bennett (2007) has argued that students have their own ideas about learning space and can be very articulate in discussing the strengths and shortcomings of designed spaces.

\section{Method}

\section{Context: Two Contrasting Learning Spaces}

Two contrasting learning spaces in a middle-sized Chinese university (alias " $\mathrm{N}$ University") were selected for investigation. Both were generic learning spaces designed for all types of students. N University and the two cases were selected for two main reasons. First, N University is committed to the highest standards 
of research and teaching in architecture and civil engineering, both in China and internationally. It founded its own Architectural Design and Research Institute in the late 1950s, which is now one of the leading design institutes in China and reputable for its campus building design. On the campus of $\mathrm{N}$ University, there are many traditional, didactic spaces built in the 1950s, as well as a series of flexible, innovative learning spaces built since the 1990s. The learning paradigms that drive this transformation provide an intriguing background for the study, and the tension between the two different types of learning spaces are currently common in many other places. Secondly, the selection was made also based on the consideration of accessibility to research participants and relevant resources (e.g. the archives).

Document analysis and semi-structured interviews with educators and designers reveal that the two spaces are embedded with different intentions. Space A (Fig. 1) places great emphasis on discipline and collectivism, reflected in its traditional academic architectural style, plain colours and didactic interior space. Space B (Fig. 2) is designed to create a relaxing, interdisciplinary environment with a rich colour scheme, comfortable furnishing, spatial division and flexibility and the creation of a sense of ownership and autonomy. To some extent, the two spaces represent two distinct pedagogical philosophies and teaching approaches: in Space A, knowledge is mainly presupposed as transmission from an external source to the learner, and the teacher is the directing agency. Students are expected to be disciplined and well behaved for the acquisition of knowledge. Not surprisingly, a conventional,

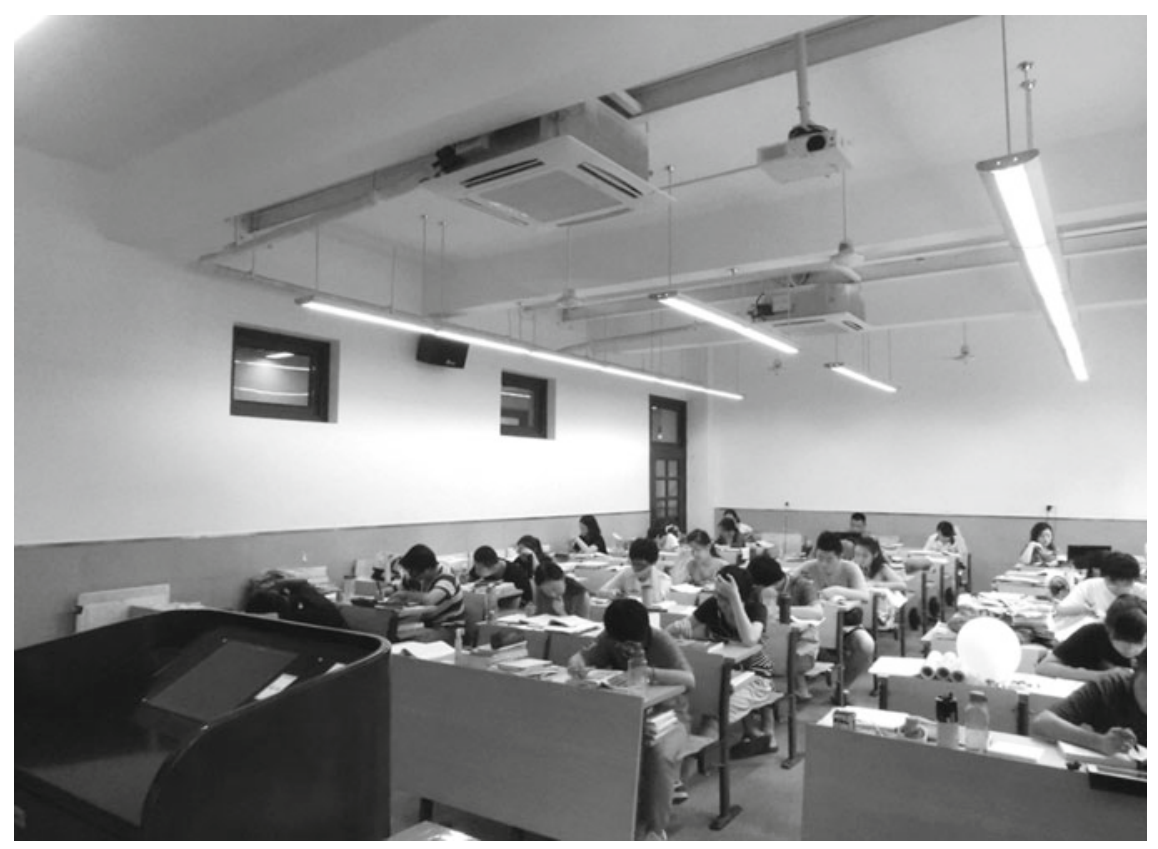

Fig. 1 The typical classroom in Space A (Photo by the author, 2015) 


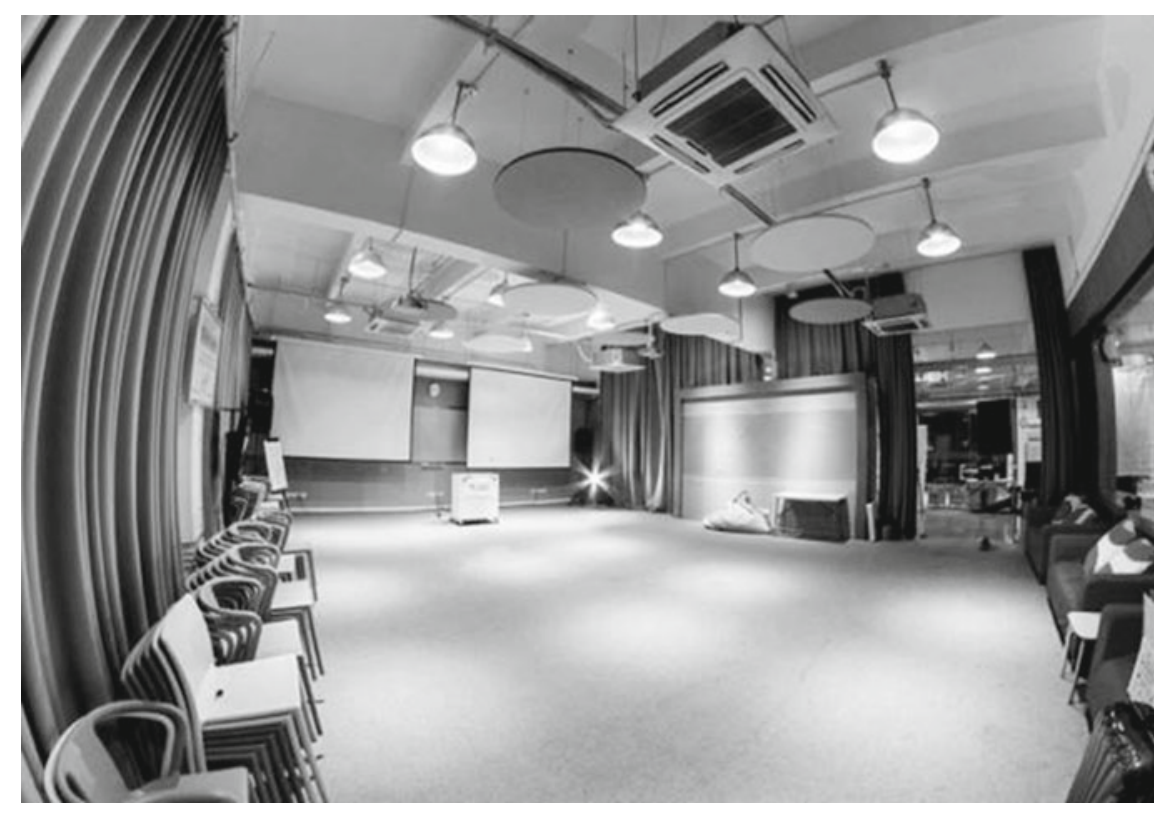

Fig. 2 Multi-purpose lecture room in Space B (Photo source: Sino-Finnish Centre)

teacher-focused approach is used in which the teacher determines the subject matter, often in the form of books or chapters, the content of which has to be learned.

By contrast, in Space B learning is more closely conceived as an active process of knowledge construction. As the designer describes, "we use vivid colour, natural materials, and displays (things you will never see in common teaching buildings) to inspire students' ideas and imagination...students are not judged by correct or wrong answers; instead, they are encouraged to think and participate actively". Space B provides a number of courses on product design and innovation, which normally employs a project-based learning approach with students from different disciplines choosing authentic, real-life assignments or problems to work on, and working in small groups. The role of the teacher is to guide the groups and provide feedback when necessary. Students can use both spaces freely when there are no scheduled classes and events.

\section{Focus Group Interviews}

Prior to this study, a survey was conducted with 320 students on their learning strategies within the two spaces. The findings suggested that students in Space A and Space B differed in many respects in terms of the central dimensions of learning as noted above-cognitive strategies, regulative strategies and learning motivations 
(Yu et al., 2019). However, questionnaires gave limited information about how the differences occurred and what specific role space played in the complicated learning process; neither they could reveal the crucial student view on the phenomenon. Thus, in this study, to explore students' experiences and attitudes further in depth, students were recruited to participate in focus group interviews (FGIs), in which they were asked a series of open-ended questions about (1) how they understood 'learning space'; (2) how they learned within the space where the FGI took place; (3) how they considered the impact of space on their learning; and (4) how they responded to the previous survey results. The researcher stayed open to new ideas put forward by participants, and probes were used during the process. To reduce the influence of dominant voices and to obtain comparable data from all respondents, in the middle of the FGIs, students were given a chance to independently write down the influential elements of a space to their learning.

Participants were selected for each FGI with the aim of capturing as much variation as possible on the following variables: gender, year of study and academic discipline. This was based on the consideration that both spaces are generic learning spaces, and also because previous student learning research has shown that these variables are related to how students go about their learning (Richardson, 2000; Vermunt, 2005). The group size was set at four to six participants after a pilot study. Finally, six FGIs with a total of 28 participants were conducted. Each FGI lasted between 1 h 40 min and $2 \mathrm{~h}$.

\section{Data Analysis}

The recordings of all FGIs were manually transcribed. Coding was conducted, which was an iterative process before arriving at stable elements and categories. Drawing on the conceptual basis of student learning as described above, the development of specific code scheme used a bottom-up strategy to produce the results through a more emergent encounter with the data themselves. About $20 \%$ of the overall transcriptions were coded by a second independent researcher to assess the inter-rater reliability. Below four overarching themes regarding the alignment between learning space and student learning are outlined, and the identified codes are indicated with ". 


\section{Selected Results}

\section{Theme One: Learning Space and Students' Conceptions of Learning}

On the whole, this theme is associated with how students view and conceive their learning. Students in Space A mostly saw learning space simply as a physical site for learning, as they considered learning is 'the increase of knowledge' and 'the acquisition of facts and skills', which can be retained and/or utilised in practice. In contrast, students in Space B discussed more about 'cooperation' and 'interpretation' aimed at the understanding of reality, and paid more attention to intangible benefits of learning space, for instance, 'enrichment of learning opportunities' and 'possibility of 'communication'.

\section{Theme Two: Learning Space and Cognitive Aspects of Learning}

Students described that learning space is related to how they process their subject matter in a particular way: they were more likely to use 'listening/memorising' in a traditional space like Space A, and more engaged in 'relating/structuring/creating thinking' and 'group discussion' in an innovative learning environment like Space B. It means that student learning in Space A is engaged as a process of listening to the instruction of the teacher and repeating definitions, formulas, memorising theories and rehearsing subject matter regularly in the conventional classroom, while in Space $\mathrm{B}$, students reported a collaborative process of looking for connections between different parts and the merging of new ideas.

\section{Theme Three: Learning Space and Affective Aspects of Learning}

Space is also associated with affective and motivational aspects of student learning, including their 'learning motivation', 'emotions' and 'concentration effort'. This means in the FGIs: (1) Students described a reason or reasons for acting or behaving in a particular way in a space, especially the reason in deciding where to learn. (2) Students discussed either positive feelings of happiness, ownership, self-confidence when they learned within the space; or negative emotions, such as anxiety, stress, insecurity and helplessness. (3) Students also talked about the action-distracting, 
task-irrelevant emotions that arise during their learning within the space. As a student summarised at the end of one FGI:

If we could divide the composition of a learning space into three levels of factors-some level largely determines whether I will choose to learn or not learn there, the others affect the emotions during my learning, and another is associated with the degree of how effectively I can learn. All these factors of space, through exerting influence on my subjective feeling, willingness, self-initiation and effectiveness of learning, consequently impact upon the attitude, method and outcome of my learning.

\section{Theme Four: Learning Space and Regulative Aspects of Learning}

Learning space is also in relation to students' regulative learning activities. The data easily distinguish between 'self-regulation' and 'external regulation'- the former refers to students' self-initiated orienting, planning and adjustment of their learning process and activities through their examination of characteristics of the learning task and the situation within the learning space, while the latter is related to the control of teaching, other students and the surrounding events. 'Flexibility of space' in Space B facilitates students' 'self-regulation', while a conventional classroom with 'fixed seating arrangement' like Space A engenders a feeling of tension and relates to 'external regulation'. Below are two examples:

(A student in Space A) When I learn here, the surrounding people have an effect on me, I guess, it is called 'group effect'. If others around you are playing or doing something irrelevant, I won't have much mood for learning.

(A student in Space B) When I learn here, for instance, I need to draw something, then I can easily get a small whiteboard to clear my mind. I feel I can control something by myself, make adjustments and go back to learning.

\section{Conclusion}

The initial motivation for the present study derives from the curiosity about two fundamental questions rooted in learning space research: Does it really matter where students learn? How does it matter for student learning? Research on learning spaces and theories of student learning styles in higher education are rarely connected; this chapter tries to provide a window into what that phenomenon may encompass. It draws, from a larger study, a selection of themes and suggests that, with these participants in a Chinese setting, an innovative learning environment can lead to a crucial change in students' views on learning - from the acquisition of facts and skills to an active constructive process, and consequently facilitate a more collaborative, selfregulated, problem-based learning approach. As a number of empirical studies have shown that these learning strategies are associated with better learning outcomes (see e.g. Biggs, 1999; Van Rossum \& Schenk, 1984; Vermunt, 2003), we may conclude 
that an innovative learning environment like Space B does support a more desirable approach to learning in higher education than a traditional classroom like Space A.

The results also suggest that students' emotional reactions and motivation consequences of the attributes of a space need to be carefully considered during design and in the ongoing management. Many learning spaces (like the two investigated here) are not only designed for teaching purposes but also for students' self-study activities. Therefore, students' attitudes towards a space not only affect their learning processes in class but also relate to where students choose to learn after class and how efficiently a space is utilised. In terms of the generalisability of the findings, this study takes place in China, but there is no clear evidence showing that participants' use of learning space is culturally determined. Meanwhile, the two selected cases are representative in terms of their contrasting pedagogical aims and physical features, which are currently common in many other places. From this point of view, the results are transferrable in different contexts.

The theoretical rationale underpinning student learning research may be worthy of consideration by learning space researchers as the multifacetedness of learning has been investigated extensively in this area, providing greater insight into the dynamic learning process and a number of formal inventories to measure student learning. In making an alliance between our understanding of pedagogy, space and learning, the integration between two research domains is likely to generate a fruitful prospect. It is hoped that this study sheds some light on this large issue that requires substantial research in the future.

Acknowledgments The author wishes to thank the participants and the management staff of the two spaces for their cooperation in the study and permission for accessing relevant materials and records. Data utilised in this research was obtained in adherence to the required ethical protocol of the author's host institution. All images and diagrams are the property of the author, or the author has obtained consent to use them from the appropriate copyright owner.

\section{References}

Ballard, N., \& Clanchy, J. (1984). Study abroad: A manual for Asian students. Kuala Lumpur: Longman.

Beetham, H., \& Sharpe, R. (Eds.). (2013). Rethinking pedagogy for a digital age. New York: Routledge.

Bennett, S. (2007). Designing for uncertainty: Three approaches. The Journal of Academic Librarianship, 33(2), 165-179. https://doi.org/10.1016/j.acalib.2006.12.005.

Biggs, J. B. (1988). Assessing student approaches to learning. Australian Psychologist, 23(2), 197-206. https://doi.org/10.1080/00050068808255604.

Biggs, J. (1993). What do inventories of students' learning processes really measure? A theoretical review and clarification. British Journal of Educational Psychology, 63, 3-19. https://doi.org/10. 1111/j.2044-8279.1993.tb01038.x.

Biggs, J. (1999). Teaching for quality learning at university: What the student does. Buckingham: SRHE \& Open University Press. 
Brooks, C. (2011). Space matters: The impact of formal learning environments on student learning. British Journal of Educational Technology, 42(5), 719-726. https://doi.org/10.1111/j.1467-8535. 2010.01098.x.

Brooks, C. (2012). Space and consequences: The impact of different formal learning spaces on instructor and student behaviour. Journal of Learning Spaces, 1(2). Retrieved from http://libjou rnal.uncg.edu/index.php/jls/article/view/285.

Ellis, R. A., \& Goodyear, P. (2016). Models of learning space: integrating research on space, place, and learning in higher education. Review of Education, 4(2), 149-191. https://doi.org/10.1002/ rev3.3056.

Entwistle, N., \& Ramsden, P. (1983). Understanding student learning. London: Croom Helm.

Entwistle, N., McCune, V., \& Hounsell, D. (2002). Occasional report 1: Approaches to studying and perceptions of university teaching-learning environments: concepts, measures and preliminary findings. Retrieved from http://www.ed.ac.uk/etl.

Geertz, C. (1973). The interpretation of cultures. New York: Basic Books.

Harrison, A., \& Hutton, L. (2014). Design for the changing educational landscape: Space, place and learning. Abingdon: Routledge.

Hau, K.T., \& Ho, I. T. (2010). Chinese students' motivation and achievement. In M. H. Bond (Ed.), Oxford handbook of chinese psychology (pp. 187-204). Oxford: Oxford University Press.

Joint Information Systems Committee (JISC) (2006). Designing spaces for effective learning: A guide to 21 st century learning space design. Retrieved from http://www.jisc.ac.uk/whatwedo/pro grammes/elearninginnovation/learningspaces.aspx.

Kember, D. (1996). The intention to both memorise and understand: Another approach to learning? Higher Education, 31(3), 341-354. https://doi.org/10.1007/BF00128436.

Lu, G. (2003). 大学生学习风格量表的设计与开发 [The development of the inventory of learning styles for undergraduate students]. Journal of Xi'an Jiaotong University (Social Sciences), 23(2), 86-97. https://doi.org/10.3969/j.issn.1008-245X.2003.03.017.

Marton, F., \& Säljö, R. (1984). Approaches to learning. In F. Marton, D. Hounsell, \& N. Entwistle (Eds.), The experience of learning (pp. 36-55). Edinburgh: Scottish Academic Press.

Mirijamdotter, A., Somerville, M. M., \& Holst, M. (2006). An interactive and iterative evaluation approach for creating collaborative learning environments. The Electronic Journal of Information Systems Evaluation, 9(2), 83-92. Retrieved from https://www.researchgate.net/publication/228 627177_An_interactive_and_iterative_evaluation_approach_for_creating_collaborative_lear ning_environments.

Murphy, D. (1987). Offshore education: A Hong Kong perspective. Australian Universities' Review, 30(2), 43-44. Retrieved from https://files.eric.ed.gov/fulltext/EJ364973.pdf.

Oblinger, D. G. (2006). Learning spaces. EDUCAUSE. Retrieved from https://www.educause.edu/ research-and-publications/books/learning-spaces.

Richardson, J. T. E. (2000). Researching student learning: Approaches to studying in campus-based and distance education. Buckingham, UK: Open University Press.

Richardson, J. T. E., \& Sun, H. (2016). Approaches to studying among international students from China. In D. Jindal-Snape \& B. Rienties (Eds.), Multi-dimensional transitions of international students to higher education (pp. 106-122). New York: Routledge.

Samuelowicz, K. (1987). Learning problems of overseas students: Two sides of a story. Higher Education Research and Development, 6(2), 121-133. https://doi.org/10.1080/072943687006 0204.

Schmeck, R. R. (1988). Learning strategies and learning styles. New York: Plenum Press.

Short, E. J., \& Weisberg-Benchell, J. A. (1989). The triple alliance for learning: Cognition, metacognition and motivation. In C. B. McCormick, G. E. Miller, \& M. Pressley (Eds.), Cognitive strategy research: From basic research to educational applications (pp. 33-63). New York: Springer Verlag.

Strange, C., \& Banning, J. (2001). Educating by design: Creating campus learning environments that work. San Francisco: Jossey-Bass. 
Temple, P. (2008). Learning spaces in higher education: An under-researched topic. London Review of Education, 6(3), 229-241. https://doi.org/10.1080/14748460802489363.

Van Russum, E, J., \& S. M. Schenk (1984). The relationship between learning conception, study strategy and learning outcome. British Journal of Educational Psychology, 54(1), 73-83. https:// doi.org/10.1111/j.2044-8279.1984.tb00846.x.

Vermunt, J. D. (2005). Relations between student learning patterns and personal and contextual factors and academic performance. Higher education, 49(3), 205-234. https://doi.org/10.1007/ s10734-004-6664-2.

Vermunt, J. D. (2003). The power of learning environments and the quality of student learning. In E. de Corte, L. Verschaffel, N. Entwistle, \& J. van Merriënboer (Eds.), Powerful learning environments: Unravelling basic components and dimensions, Advances in learning and in learning and instruction series (pp. 109-124). Oxford: Pergamon.

Vermunt, J. D., \& Verloop, N. (1999). Congruence and friction between learning and teaching. Learning and Instruction, 9(3), 257-280. https://doi.org/10.1016/S0959-4752(98)00028-0.

Walker, J. D., Christopher, D., Brooks, C., \& Baepler, P. (2011). Pedagogy and space: Empirical research on new learning environments. EDUCAUSE. Retrieved from http://www.educause.edu/ erp/article/pedagogy-and-space-empirical-research-new-learning-environments.

Watkins, D. A., \& Biggs, J. B. (1996). The Chinese Learner: Cultural, psychological and contextual Influences. Hong Kong: Comparative Education Research Centre, University of Hong Kong.

Yin, R. K. (2009). Case study research: Design and methods. London: Sage.

Yu, J., Vermunt, J. D., \& Burke, C. (2019). Students' learning patterns and learning spaces in higher education: An empirical investigation. Manuscript submitted for publication.

Zhu, C., Valcke, M., \& Schellens, T. (2008a). A cross-cultural study of Chinese and Flemish university students: Do they differ in learning conceptions and approaches to learning? Learning and Individual Differences, 18(1), 120-127. https://doi.org/10.1016/j.lindif.2007.07.004.

Zhu, C., Valcke, M., \& Schellens, T. (2008b). The relationship between epistemological beliefs, learning conceptions, and approaches to study: A cross-cultural structural model? Asia Pacific Journal of Education, 28(4), 411-423. https://doi.org/10.1016/j.lindif.2007.07.004.

Ji Yu (China) obtained her doctoral degree from the University of Cambridge, Faculty of Education. She holds an MA in education from Beijing Normal University and a BA in engineering from Tongji University. Her research focuses on improving the quality of student learning by introducing new configurations of learning space in higher education. She also studies the role of university innovation in contributing to a better, sustainable society. Her research has been funded by China's Ministry of Education and Postdoctoral Science Foundation. Recently, Ji completed her postdoctoral research at Peking University.

Open Access This chapter is licensed under the terms of the Creative Commons Attribution 4.0 International License (http://creativecommons.org/licenses/by/4.0/), which permits use, sharing, adaptation, distribution and reproduction in any medium or format, as long as you give appropriate credit to the original author(s) and the source, provide a link to the Creative Commons license and indicate if changes were made.

The images or other third party material in this chapter are included in the chapter's Creative Commons license, unless indicated otherwise in a credit line to the material. If material is not included in the chapter's Creative Commons license and your intended use is not permitted by statutory regulation or exceeds the permitted use, you will need to obtain permission directly from the copyright holder. 